UDC: 811.111'276.6:61 https://doi.org/10.22190/JTESAP2103389V

Review research paper

\title{
A PROPOSAL FOR PROFESSIONAL DEVELOPMENT OF BUSINESS ENGLISH TEACHERS IN SERBIA - OVERVIEW OF THE RESEARCH*
}

\author{
Mirna Vidaković \\ University of Novi Sad, Faculty of Economics in Subotica, Serbia
}

\begin{abstract}
This paper gives an overview of the empirical research conducted in the doctoral thesis entitled "A New Model of Professional Development of Business English Teachers in Serbia: Theoretical, Methodological and Practical Aspects". Having noticed that professional needs of Business English teachers in Serbia were not sufficiently recognized, the research aimed to analyse the current situation regarding Business English teaching and professional development of teachers so as to gain data necessary for creating a proposal of a model of development that would fully respond to teachers' pedagogical demands. The sample included 85 teachers and 349 students of Business English. Data collected through questionnaires and interview were analysed quantitatively and qualitatively. The results were largely consistent with contemporary research in the fields of LSP (Languages for Specific Purposes) and professional development of teachers. A few points which reflected a traditional approach to education concerned students' perception of teachers' roles and field competencies, and teachers' expectations with regard to obtaining ready-made pedagogical solutions. The proposed model advocates a bottom-up and reflective approach to professional development, encourages both self-directed learning and collaboration, and offers content that suits teachers' diverse experience and working contexts.
\end{abstract}

Key words: Business English, Business English teacher, competence, professional development

\section{INTRODUCTION}

The field of Languages for Specific Purposes (LSP) and, within it, Business English, has gained prominence in the $21^{\text {st }}$ century as students and working people increasingly require foreign language knowledge and skills to enhance their employment prospects and cross-border mobility. Internationalisation of education, business and workforce in Serbia, too have created a growing demand for general and specialised Business English courses. Business English was introduced as an obligatory/elective course in secondary schools of economics in the school year 2012/2013. This area of LSP has gained a more significant place in tertiary education as well, with the rising number of institutions offering study

Submitted November $25^{\text {th }}, 2020$, accepted for publication February $23^{\text {rd }}, 2021$

Corresponding author: Mirna Vidaković. Faculty of Economics in Subotica, Segedinskiput 9-11, 24000 Subotica, Serbia |E-mail: mirna.vidakovic@ef.uns.ac.rs

* This paper presents an overview of the author's PhD thesis entitled "A New Model of Professional Development of Business English Teachers in Serbia - Theoretical, Methodological and Practical Aspects“, which was defended at the Faculty of Philosophy, University of Novi Sad in 2016. 
programmes in business and economics ${ }^{2}$. Finally, private schools of foreign languages have swiftly responded to newly created professional needs of business people in terms of foreign language competencies and started running Business English courses both at their premises and in-company. All of this has put an increased pressure on teachers to adequately meet diverse educational and professional requirements of their students.

Having in mind that devising and implementing Business English courses requires a broader scope of knowledge and skills compared to teaching General English (e.g. subject specific knowledge, competencies to administer needs analysis, adapt or create teaching resources within the students' professional disciplines, etc.), Business English teachers need to be given opportunities to build and strengthen both general and subject-specific knowledge and skills which enable them to deliver effective and high-quality courses.

Analysis of professional development programmes in Serbia relevant for Business English teachers, which covered the period from 2010 onwards, showed that pedagogical needs of these teachers have not been recognized sufficiently. For example, the examination of content in The Catalogue of Programmes for Continuous Professional Development of Teachers, Preschool Teachers and Professional Associates, which is particularly relevant for teachers in secondary education, revealed that programmes directly targeting Business English teachers have almost been non-existent.

The only professional development activities that maintain continuity are the LSP conference organized by Foreign Language and Literature Association of Serbia (FLLAS) with its Language for Specific Purposes Special Interest Group (LSP SIG) and the University of Belgrade, which takes place every third year, and the biennial ESP conference held at the University of Niš.

Other resources that teachers can use to keep up with pedagogical research and practice are professional journals such as this one - Journal of Teaching English for Specific and Academic Purposes, published by the University od Niš, and ESP Today, published by the Faculty of Economics in Belgrade.

Teachers can also attend international conferences, webinars, etc. organized by international associations such as IATEFL BESIG $^{3}$ or publishing houses such as Macmillan or Cambridge. However, these events are not fully recognized in the professional development system of teachers in Serbia and are not always financially accessible.

Therefore, to improve the situation with regard to enhancing professional competencies of Business English teachers in Serbia, the author conducted empirical research. More preciselly, the aim was to analyse the areas of Business English teaching and professional development so as to obtain guidelines which would help to create a proposal for professional development that would adequately respond to teachers' pedagogical needs. Since it is not possible to give a detailed account of such extensive study in one article, this paper will focus only on a few main theoretical points, and give a brief overview of the empirical research and the proposal of a model of professional development.

\footnotetext{
${ }^{2}$ Economics comprises fields such as marketing, management, business informatics, commerce, accounting, etc.

${ }^{3}$ IATEFL BESIG stands for International Association of Teachers of English as a Foreign Language - Business English Special Interest Group
} 


\section{PROFESSIONAL DEVELOPMENT AND COMPETENCIES OF BUSINESS ENGLISH TEACHERS}

There is a significant body of research that addresses professional development and competencies, and highlights the key role that these two concepts play in teachers' profession (Beara and Okanović 2010; Darling-Hammond 2006; Džinović 2010; Foord 2009; Glušac 2016; Pešikan et al. 2010; Polovina and Pavlović 2010; Richards and Farell 2005; Rangelov Jusović, Vizek Vidović, and Grahovac 2013). In addition to describing contemporary principles that underpin professional development, these studies help teachers to identify their pedagogical needs and create their own professional development path.

As far as the main features of contemporary professional development are concerned, there is a concensus in literature (Beara and Okanović 2010; Darling-Hammond 2006; Džinović 2010; Foord 2009; Glušac 2016; Pešikan et al. 2010; Polovina and Pavlović 2010; Richards and Farell 2005; Richardson and Diaz Maggioli 2018) that it is a continuous, lifelong process which leads to "deep and lasting changes in teacher cognition and performance" (Richardson and Diaz Maggioli 2018, 7). Teachers are viewed as reflective practitioners who actively engage in critical inquiry of their practice, values, and attitudes. They are expected to adopt the self-directed approach to learning. However, ensuring institutional support also plays a significant part in this process. Furthermore, taking into account the complexity and dynamic nature of teaching knowledge and skills, individual learning should be accompanied by collaboration with peers and other relevant participants in education through sharing of knowledge and experiences by means of face-to-face and virtual communication.

Teacher competencies constitute the core of professional development and are perceived as standards that contribute to professionalization of teachers' profession (Stanković 2010). Many frameworks of teacher competencies have been designed, and they largely resemble each other in terms of content. This comes as no surprise having in mind that they draw on contemporary research of professional development and construction of knowledge. The framework that served as a basis for the research presented in this paper was created by Selvi (2011). It is aimed at English language teachers and takes into account their various professional roles both inside and outside the classroom. The framework is suitable for Business English teachers as well, as it encompasses features which are specific to their working environment.

According to this framework, there are nine main categories of competencies:

1. field competencies, which refer to the "academic studies about the content" that the teacher teaches (Selvi 2011, 169);

2. research competencies, which comprise the knowledge of methods and techniques necessary to conduct research;

3. curriculum competencies, which refer to knowledge and skills that help teachers to develop and implement the curriculum;

4. lifelong learning competencies, which imply that teachers are accountable for their own professional learning throughout the career, as well as for developing their students' skills to pursue lifelong learning;

5. emotional competencies, which 'are composed of teachers' and students' values, morals, beliefs, attitudes, anxieties, motivation, empathy" (Selvi 2011, 171);

6. social-cultural competencies, which refer to the knowledge about teachers' and students' local, national and global social and cultural environment as well as the issues such as human rights, democracy, etc.; 
7. communication competencies, which include both intrapersonal and interpersonal communication, and activities such as information processing, analysing, observing, evaluating and the like;

8. information and communication technologies competencies (ICT competencies), which comprise knowledge about ICT tools and the skills to use them to "produce, manipulate, store, communicate, and/or disseminate information" (Selvi 2011, 172);

9. environmental competencies, which refer to "knowledge, attitudes and skills about ecological system and environment” (Selvi 2011, 172).

Finally, it needs to be highlighted that professional development should be based on both global contemporary research and practices, and local educational and cultural contexts so as to suitably fulfil the actual professional needs of teachers.

\section{RESEARCH METHODOLOGY}

The aim of the research in the thesis was twofold:

- to analyse the legal framework and documents with regard to teaching Business English and professional development of teachers in Serbia, so as to become acquainted with formal features and requirements related to these two components;

- to conduct empirical research, i.e. to analyse the attitudes, needs, and expectations of business English teachers with regard to professional development, and the attitudes, needs, and expectations of Business English students as to teacher roles, competencies, and courses.

Thorough examination of the above mentioned points within the contemporary theoretical framework produced data which enabled the author to create a proposal of professional development that meets the specific pedagogical needs of Business English teachers in Serbia.

The sample comprised 85 Business English teachers working in secondary and tertiary education as well as in private schools of foreign languages, and 349 students attending Business English courses in the aforementioned types of institutions. There was approximately the same share of respondents per type of institution. The gender structure of the sample is shown in Table 1.

Table 1 The structure of the sample based on gender

\begin{tabular}{|l|c|c|}
\hline Respondents & Female & Male \\
\hline Business English teachers & 81 & 4 \\
\hline Business English students & 221 & 129 \\
\hline
\end{tabular}

Business English teachers' age ranged from 23 to 58. Most of respondents belonged to the 30-39 age category $(54.1 \%)$. The same percentage of surveyed participants held a Bachelor (Hons.) and a Masters' degree (40\% per category), whereas the remaining teachers had the academic title of magister $(15.3 \%)$ or doctor $(4.7 \%)$. At the time of the research, the respondents' working experience was between 4 months and 30 years. Almost half of the teachers $(43 \%)$ taught Business English only 2-5 years, which suggests that this area of English for Specific Purposes is still relatively new in Serbia. 
Business English students' age ranged from 15 to 63 . The majority were between 16 and 21 years old $(58.7 \%)$, which was expected since around two thirds of respondents attended secondary schools or higher education institutions. At the time of the study, students were learning Business English from 2 months to 10 years. The structure of the sample according to the length of learning Business English is shown in Table 2.

Table 2 Structure of the sample (students) according to the length of learning business English

\begin{tabular}{|l|r|c|}
\hline Length of learning Business English & F & $\%$ \\
\hline Up to 1 year & 119 & 34.1 \\
\hline 2 years & 71 & 20.3 \\
\hline 3 years & 88 & 25.2 \\
\hline More than 3 years & 69 & 19.9 \\
\hline Missing & 2 & 0.6 \\
\hline
\end{tabular}

The research instrument comprised two anonymous questionnaires (one for teachers, another for students), and a semi-structured interview, which involved 8 teachers. The questionnaires were administered in the period between October 2014 and February 2015, whereas the interview took place during May and June 2015. Data processing included a quantitative analysis (descriptive and inferential statistics) which employed the SPSS 20 package, and a qualitative analysis which was executed through content analysis. Identifying correlations between the variables was performed by the means of chi-square test, whereas Mann-Whitney and Kruskal-Wallis tests were used to establish statistically significant differences between the variables. The inclusion of different types of research participants and instruments ensured greater reliability of data and helped to obtain a more comprehensive picture of the subject of the research.

\section{BRIEF SUMMARY OF KEY RESEARCH FINDINGS}

This section gives a brief summary of key findings of the research conducted with Business English teachers (4.1.) and Business English students (4.2.).

\subsection{Research findings: Business English teachers}

The analysis of results obtained through the survey and the interview with Business English teachers confirmed that they are aware of the importance of professional development for improving their pedagogical competencies and performance, but that their professional needs are not sufficiently recognized.

The great majority of respondents $(88 \%)$ chooses programmes based on the relevance and importance for their professional growth, which suggests that teachers are able to critically approach their pedagogical practice and identify its strengths and weaknesses. On the negative side, however, only $17 \%$ of respondents said that the current offer of professional development activities was adequate, whereas slightly over half of surveyed participants (51\%) claimed that they did not have sufficient opportunities for strengthening relevant competencies. Failure to respond to teachers' professional needs might be part of the cause of lower frequency of participation in professional development programmes. Namely, the 
research showed that $52 \%$ of teachers take part in professional development activities only once or twice a year, which cannot contribute to deeper and lasting changes in pedagogical practice, values, and attitudes. Six teachers even said that they did not attend professional development programmes. Both surveyed and interviewed respondents working in secondary education felt that the teaching profession was undervalued and insufficiently recognized, which inevitably impacted their motivation to participate in professional development activities. Such situation calls for action, particularly because almost two thirds of the surveyed participants (67\%) reported that they had not undergone adequate professional training before they started pursuing career in Business English teaching.

As for the types of professional development activities that teachers undertake, the largest portion attends seminars (82.4), reads professional journals (70.6\%), and participates in conferences (67.1). The structure of respondents according to the type of professional development activity that they engage in can be seen in Table 3.

Table 3 Structure of respondents (teachers) according to the type professional development that they undertake

\begin{tabular}{|l|c|c|}
\hline Type of professional development activity & F & $\%$ \\
\hline Seminars & 70 & 82.4 \\
\hline Reading professional journals & 60 & 70.6 \\
\hline Conferences & 57 & 67.1 \\
\hline Workshops & 39 & 45.9 \\
\hline Observations and peer coaching & 34 & 40 \\
\hline Webinars & 31 & 36.5 \\
\hline Professional learning networks (PLN) & 25 & 36.5 \\
\hline Courses and trainings & 24 & 28.2 \\
\hline Online conferences & 24 & 28.2 \\
\hline Action research & 13 & 15.3 \\
\hline Keeping professional development portfolio & 10 & 11.8 \\
\hline Winter and summer schools & 9 & 10.6 \\
\hline
\end{tabular}

The types of activities that teachers consider most effective for their pedagogical practice are observations, peer coaching and participation in professional learning networks. This confirms that collaboration plays a vital role in enhancing teaching practice. The problem, however, lies in the fact that this result does not correspond with the one relating to participation in different types of activities (Table 3), i.e. the aforementioned forms of professional development are undertaken by a smaller share of respondents $(40 \%$ and $36.9 \%$ respectively).

The majority of surveyed participants $(80 \%)$ want to be offered more of virtual professional development opportunities as they are less costly and allow for a more flexible approach to learning and improving competencies.

Teachers expressed a high level of need for strengthening the following professional areas: 
- ICT competencies in business English context $(85 \%)^{4}$;

- field competencies, i.e. competencies related to students' professional discipline $(78.8 \%)$;

- knowledge and skills related to relevant scientific research concerning learning and teaching processes, and languages for specific purposes, i.e. business English (70.6\%);

- communication competencies (70.6\%);

- curriculum development competencies $(69.4 \%)$;

- curriculum implementation competencies (68.2\%).

The result suggests that business English teachers' needs are not met adequately in the system of professional development in Serbia.

In addition to the aforementioned competencies, respondents also highlighted the need to enhance knowledge and skills related to developing student autonomy and motivation. They also pointed to the importance of recognizing different types of professional demands that teachers have at different stages of their career, which rules out "one size fits all" professional development model.

The issue that was also raised in the research concerned the implementation of newly acquired knowledge and skills in the teaching practice, as well as the need to introduce mechanisms to monitor this process as a way of supporting teachers throughout their professional journey.

Finally, teachers said that the following factors contribute to the effectiveness of professional development programmes: responding to professional needs, active participation, interactivity, inventiveness, cooperation, continuity, and educators who are thoroughly acquainted with pedagogical theory, practice, and teachers' working environment.

All the research findings mentioned in this section so far are in line with contemporary perception of professional development. However, one point was identified in the analysis which reflected the traditional approach to learning. Namely, a significant portion of teachers expect ready-made pedagogical solutions from professional development programmes. This is in contrast with the constructivist approach to learning, where learners, i.e. teachers in this case, are encouraged to build knowledge based on their experience and the tools that they are provided in these activities. Teachers' dissatisfaction with the extent to which professional development events fulfil their needs might actually be partly linked to such traditional perception.

\subsection{Research findings: Business English students}

Students' answers to the questions in the survey gave insight into their motivation for learning Business English, and opinions and expectations with regard to teachers' roles, competencies, and the importance of various course aspects for their learning experience and outcomes.

The study showed that slightly over half of surveyed participants learn Business English for several reasons, the main ones being that the course is the integral part of the syllabus, that it helps to improve knowledge and skills in students' professional context, and that it increases their employment and career opportunities. A correlation was

\footnotetext{
${ }^{4}$ Teachers were asked to express their level of need for improving different groups of competencies on a scale from 0 (no need) to 4 (a very high level of need). The given percentage represents the share of teachers who selected options 3 (a high level of need) and 4 (a very high level of need).
} 
identified between the type of the institution that students attend and the reason for learning Business English. Namely, students in secondary schools, and to a lesser degree in tertiary education, are less aware of the need to acquire Business English competencies for their future professional orientation compared to their employed counterparts. This comes as no surprise since the needs of pre-experience students, i.e. the students who do not have any working experience are mostly delayed compared to job-experienced students' needs, which are generally immediate.

Students said that Business English courses need to be in line with their professional interests and experience, though general global topics, such as human rights, environmental issues and the like are welcome as well, particularly as part of general Business English courses. In their opinion, factors that make classes engaging and enjoyable are innovative content, interaction and collaboration with peers, active participation in classroom activities and devising the course content (the latter is significant for job-experienced students). Teachers' personality and competencies also play a very significant role, especially their ability to communicate and build respectful and supportive relationship with students.

The above mentioned observations correspond with the research in the field of LSP (Donna 2000; Ellis and Johnson 1994; Frendo 2005; Ignjačević 2012). However, the analysis also revealed that students' understanding of teachers' field competencies and their role in the classroom reflects the traditional approach to education. Namely, $83.1 \%$ of respondents were of the opinion that in addition to possessing linguistic competencies, teachers need to be able to demonstrate the expert level of content knowledge related to students' professional discipline. Today, there is a consensus in literature (Day and Krzanowski 2011; Donna 2000; Ellis and Johnson 1994; Ignjačević 2012) that LSP and Business English teachers are primarily teachers of a foreign language. They should, however, show willingness to continuously improve knowledge and skills related to their students' professional discipline so as to be able to maintain meaningful interaction in classes.

As for teachers' roles, a significant portion of respondents (67.3\%) expressed a traditional view of teachers as suppliers of knowledge rather than facilitators who encourage students' active engagement in the construction of knowlegde. Such result calls for action in terms of developing student autonomy.

Finally, speaking of integration of information and communication technologies (ICT) in Business English courses, students' opinions were divided $-45.6 \%$ consider ICT a significant component of Business English classes, whereas 54.5\% gave neither positive nor negative response, ${ }^{5}$ or were of the opinion that it does not play a significant role in the teaching and learning processes. Taking into account the growing importance of ICT in education, this result might be linked to the fact that classrooms in Serbia are not properly equipped and that there are teachers who lack competencies to successfully add an ICT dimension to their courses.

\footnotetext{
${ }^{5}$ These students selected "neither agree, nor disagree" option.
} 


\section{Proposal of A MODEl of BUSINESS ENGLiSH TEACHERS' PROFESSIONAL DEVELOPMENT}

The results obtained from the research and their interpretation within the relevant theoretical framework offered a sound foundation for devising a proposal of professional development of Business English teachers in Serbia. The model was described in terms of its general features and content, and is presented below.

As for the main features, the model of professional development should:

- be based on a bottom-up approach, where teachers are encouraged to reflect on their practice and equipped to find pedagogical solutions which meet their professional needs;

- encourage both collaboration and individual learning, where collaboration includes not only teachers, but all relevant participants in education. Collaboration provides teachers and other parties with multiple perspectives and thus contributes to higherquality professional engagement. Additionally, it strengthens the relationship between the peers;

- motivate teachers to implement newly acquired knowledge and skills in their teaching. To this end, devising mechanisms to monitor integration of new ideas, methodologies, etc., would be of great importance as a way to support teachers throughout the process of development and teaching. Such mechanisms would also help teacher trainers to obtain relevant information regarding the effectiveness of professional development activities;

- include a greater number of virtual or hybrid forms ${ }^{6}$ of professional development. As has already been said in the paper, virtual activities are more accessible to teachers, less costly and usually allow more flexibility in terms of time of participation and pace of learning.

At the level of content, professional development offer should contain the following categories of programmes:

- programmes which help teachers to acquire and/or enhance professional competencies while taking into account their working experience and specific features of their teaching contexts (e.g. teaching Business English in high schools differs considerably from working with adult, job-experienced students). The main competencies that should be addressed are: field competencies, curriculum competencies, communication and ICT competencies, and competencies to enhance student autonomy and motivation;

- programmes which allow teachers with longer working experience to develop competencies in more narrowly defined areas of business English/LSP teaching theory and practice (e.g. business communication, international negotiation, etc.);

- programmes which equip teachers to give pedagogical support to their peers with regard to teaching Business English and planning their professional development (e.g. supervision, mentoring, coaching, etc.).

Catering for diverse professional needs of Business English teachers strengthens their motivation for professional growth and prevents burnout.

\footnotetext{
${ }^{6}$ Hybrid forms of professional development combine face-to-face activities with virtual ones.
} 
Finally, it needs to be mentioned that a professional development model for Business English teachers can be implemented successfully if all relevant interested parties (teachers, supervisors, policy makers, etc.) share the same understanding of the following main concepts:

- the concept of contemporary and high-quality Business English teaching;

- the concept of a competent Business English teacher;

- the concept of contemporary professional development.

\section{CONCLUSION}

This paper has given an overview of key findings and conclusions from the empirical research conducted in the $\mathrm{PhD}$ thesis entitled "A New Model of Professional Development of Business English Teachers in Serbia: Theoretical, Methodological and Practical Aspects". The research aimed to analyse the current situation with regard to teaching Business English and professional development of teachers in Serbia so as to obtain data necessary to devise a model of professional development which would fulfil teachers' pedagogical needs and correspond with contemporary theoretical and practical principles in the given areas.

The study involved both Business English teachers and students. The data, which were collected through the questionnaires and the interview, were analysed quantitatively and qualitatively. The results showed that although Business English courses are in expansion, Business English teachers' professional needs are not adequately met.

The attitudes and opinions that teachers expressed in the survey were mainly in line with recent research, showing that they are familiar with the ever increasing requirements of their profession, and, consequently, aware of the importance of continuously strengthening professional knowledge and skills. However, the opportunities for their professional development in Serbia are scarce. This is reflected in the low participation in professional development activities and the high level of need which teachers expressed for enhancing competencies to successfully devise and deliver Business English courses.

As for learners, the research revealed that their motivation for learning Business English corresponds with their characteristics, i.e. job-experienced students better understand the significance of learning Business English for their employment and career opportunities compared to pre-experience students. In students' opinion, teachers' communication competencies and support can positively impact their learning experience. However, students' perception of teachers as knowledge providers reflects the traditional approach to education. This is not unexpected having in mind that the traditional educational setting is still present in Serbia to a certain extent.

The theoretical framework and the obtained results provided a foundation for the creation of a proposal for professional development of Business English teachers in Serbia. It was concluded that the model should employ a bottom-up approach, encourage both individual learning and collaboration, enable continuous pedagogical support to teachers, and in addition to face-to-face activities offer virtual professional development opportunities as well. The content should be tailored so as to suit teachers' diverse professional needs.

This thesis has certain limitations. For example, the use of additional research instruments (e.g. observations) and involvement of other relevant parties (e.g. policy makers responsible for creation of professional development programmes) would help to achieve greater level of objectivity and shed more light on the research problem. 
However, despite the limitations of the study, its contribution to the fields of teaching business English and professional development of teachers in Serbia is still valuable. The research provides teachers and other interested parties with a comprehensive picture of the current situation in the area of professional development and has important pedagogical implications in terms of application of the model of professional development in practice.

\section{REFERENCES}

Beara, Mirjana, and Predrag Okanović. "Spremnost na profesionalni razvoj nastavnika: Kako je izmeriti?” Andragoške studije no. 1 (2010): 47-60.

Darling-Hammond, Linda. "Constructing 21st-Century Teacher Education." Journal of Teacher Education 57, no. X (2006): 1-15.

Day, Jeremy, and Mark Krzanowski. Teaching English for Specific Purposes: An Introduction. Cambridge: Cambridge University Press, 2011.

Donna, Sylvie. Teach Business English. Cambridge: Cambridge University Press, 2000.

Džinović, Vladimir. "Principi podsticanja individualne promene u profesionalnom razvoju nastavnika." In Teorija $i$ praksa profesionalnog razvoja nastavnika, edited by Nada Polovina and Jelena Pavlović, 147-170. Beograd: Institut za pedagoška istraživanja, 2010.

Ellis, Mark, and Christine Johnson. Teaching Business English. Oxford: Oxford University Press, 1994.

Foord, Duncan. The Developing Teacher. Peaslake: Delta Publishing, 2009.

Frendo, Evan. How to Teach Business English. Harlow: Pearson Education Limited, 2005.

Glušac, Tatjana. "Međusobno obučavanje kolega kao oblik stalnog stručnog usavršavanja profesora engleskog jezika: teorijski, metodološki i praktični aspekti." E diss. Filozofski fakultet Univerziteta u Novom Sadu, 2016, accessed September 4, 2020, http://digitalna.ff.uns.ac.rs/sites/default/files/db/books/edis07_Glusac.pdf\#overlaycontext=sadrzaj/2016/978-86-6065-351-4.

Ignjačević, Anđelka. Strani jezik u funkciji struke: nastava i učenje. Beograd: Filozofski fakultet Univerziteta u Beogradu, 2012.

Pešikan Ana, Antić Slobodanka, and Snežana Marinković. "Koncepcija stručnog usavršavanja nastavnika u Srbiji - između proklamovanog i skrivenog modela." Nastava $i$ vaspitanje 59, no. 2 (2010): 278-296.

Polovina, Nada, and Jelena Pavlović (eds.). Teorija i praksa profesionalnog razvoja nastavnika. Beograd: Institut za pedagoška istraživanja, 2010.

Rangelov Jusović, Radmila., Velkovski, Zoran, and Vlasta Vizek Vidović. "Okvir nastavničkih kompetencija. Pristup ATEPIE.” In Nastavnička profesija za 21. vek. edited by Vlasta Vizek Vidović and Zoran Velkovski, 24-39. Beograd: Centar za obrazovne politike, 2013.

Richards, Jack C. and Thomas S. C. Farrell. Professional Development for Language Teachers. Strategies for Teacher Learning. Cambridge: Cambridge University Press, 2005.

Richardson, Silvana and Gabriel Diaz Maggioli. Effective Professional Development: Principles and Best Practice. Cambridge: Cambridge University Press, 2018, accessed October 10, 2020, https://www.cambridge.org/elt/blog/wp-content/uploads/ 2018/04/Whitepaper_TD_72dpi-FINAL-ONLINE-VERSION.pdf. 
Selvi, Kiymet. “Teachers' Competencies”. Cultura. International Journal of Philosophy of Culture and Axiology 7, no. 1 (2010): 167-175.

Stanković, Dušan. "Mesto kompetencija u profesionalnom razvoju nastavnika." In Teorija i praksa profesionalnog razvoja nastavnika, edited by Nada Polovina and Jelena Pavlović, 63-84. Beograd: Institut za pedagoška istraživanja, 2010. 